\title{
Evaluation of anti-inflammatory activity of Justicia secunda Vahl leaf extract using in vitro and in vivo inflammation models
}

\author{
Godswill Nduka Anyasor ${ }^{*}$ (D, Azeezat Adenike Okanlawon and Babafemi Ogunbiyi
}

\begin{abstract}
Background: Justicia secunda Vahl. is a medicinal plant used in ethnomedical practice as therapy to manage inflammation. Therefore, this study was designed to evaluate the anti-inflammatory activity of methanol extract of $J$. secunda leaves (MEJSL) using in vitro and in vivo inflammation models.

Methods: Seventy-percent MEJSL was prepared following standard procedure. In vitro anti-inflammatory assays were performed using heat-induced bovine serum albumin (BSA) denaturation and erythrocyte membrane stabilization assays. Carrageenan and formaldehyde induced inflammation in rat models were used to evaluate the anti-inflammatory activity of MEJSL in vivo. Diclofenac sodium was used as a reference drug. In addition, liver and kidney function assays and hematological analysis were carried out.

Results: Data revealed that varying concentrations of MEJSL significantly $(P<0.05)$ inhibited heat-induced BSA denaturation and stabilized erythrocyte membrane against hypotonicity-induced hemolysis when compared with diclofenac sodium in a concentration-dependent manner. In vivo study showed that $10 \mathrm{mg} / \mathrm{kg}$ body weight (b.w.) diclofenac sodium, 100 and $300 \mathrm{mg} / \mathrm{kg}$ b.w. MEJSL suppressed carrageenan-induced paw edema at the sixth hour by $71.14 \%, 83.08 \%$, and $89.05 \%$, respectively. Furthermore, $10 \mathrm{mg} / \mathrm{kg}$ b.w. diclofenac sodium, 100 and $300 \mathrm{mg} / \mathrm{kg}$ b.w. MEJSL inhibited formaldehyde-induced paw edema by $72.53 \%, 74.73 \%$, and $76.48 \%$, respectively. Animals treated with varying doses of MEJSL had reduced plasma aspartate aminotransferase and alanine aminotransferase activities; urea and creatinine concentrations; and modulated hematological parameters when compared with the untreated control group.

Conclusions: Findings from this study showed that MEJSL exhibited substantial anti-inflammatory actions in the in vitro and in vivo models. It also indicated that MEJSL anti-inflammatory mechanisms of action could be through interference with phase 2 inflammatory stressors, upregulation of cytoprotective genes, stabilization of inflammatory cell membranes and immunomodulatory activity.
\end{abstract}

Keywords: Justicia secunda, Anti-inflammation, Carrageenan, Formaldehyde, Hematology, And immunology

\section{Background}

Medicinal plants have been used since time immemorial to relieve symptoms and treat diseases. It has played a vital role in health care systems where a substantial population of the world depends on the use of herbs as medicine [1]. Nowadays, there is an increasing interest among researchers to investigate the pharmacological

\footnotetext{
* Correspondence: anyasorg@babcock.edu.ng

Department of Biochemistry, Benjamin S. Carson (Snr.) School of Medicine, Babcock University, llishan-Remo, Ogun State, Nigeria
}

effects and potential mechanisms of action of sundry medicinal plants using in vitro and in vivo models $[2,3]$.

Justicia secunda Vahl. which belong to the family of Acanthaceae is commonly known as "bloodroot" and "sanguinaria" in Barbados and Venezuela respectively [4, 5]. In South-Eastern Nigeria, it is locally called "obara bundu". The Ogbia people of Otuoke-Otuaba, Bayelsa, Niger-Delta region of Nigeria calls it "asindiri" or "ohowaazara". Justicia secunda grows in humid soil around rivers or creeks and can be located in tropical and pantropical regions of the world [6]. 
In folklore medicine, $J$. secunda leaves are used for treatment of wound, anemia, and pain within the abdominal region [7]. The leaf decoction of J. secunda is consumed in some parts of Nigeria, Cote-d'Ivoire, and Congo for the purpose of improving hematocrit count [8]. Justicia secunda leaves have been demonstrated to possess antisickling, antimicrobial, antihypertensive and hematinic activities $[4,6,8,9]$. The anti-inflammatory potential of $J$. secunda leaves in animal model for $24 \mathrm{~h}$ was reported by Onoja et al. [5]. Phytochemical evaluation of J. secunda leaves detected alkaloids, polyphenols, flavonoids, tannins, leucoanthocyanins, quinones and anthocyanins [8]. In addition, quindoline, luteolin, auranamide, secundarellone A, B and C, aurantamide acetate, and pyrrolidone derivatives have been documented for J. secunda leaves [10].

Inflammation is the body's protective mechanism elicited in response to mechanical injuries, microbial infections, burns, and other deleterious stimuli that may threaten the host health [11]. It can be classified as either acute or chronic inflammation. Acute inflammation occurs as an immediate response to trauma, usually between two hours while chronic inflammation occurs as an ongoing response to a longer-term medical condition $[12,13]$. Chronic inflammation has been claimed to cause the most significant death in the World [14]. Clinically, inflammation is defined as a pathophysiological process characterized by pain, redness, edema, heat, and loss of tissue function [15]. This process involves changes in blood flow, increased permeability of vascular tissues, and tissue destruction via the activation and migration of leucocytes with the synthesis of reactive oxygen species (ROS), and local inflammatory mediators, including prostaglandins, leukotrienes, and platelet-activating factors induced by phospholipase A2, cyclooxygenases, and lipoxygenases $[16,17]$.

Conventional steroidal anti-inflammatory drugs and non-steroidal anti-inflammatory drugs (NSAID) used in the treatment of acute inflammatory disorders have been unsuccessful in the treatment of chronic inflammatory disorders including rheumatoid arthritis. These conventional anti-inflammatory drugs have also been associated with unwanted side effects $[18,19]$. This has led to the search for an alternative remedy, especially from medicinal plants to treat these inflammatory disorders. Therefore, the aim of this study was to evaluate the antiinflammatory effects of MEJSL, using in vitro and in vivo inflammation models with the rationale to provide an insight into the potential anti-inflammatory mechanisms of action.

\section{Methods}

Plant material

Justicia secunda leaves were obtained in fresh condition from a farm at Usaka-Umuofor, Isiala Ngwa North, South-
Eastern, Nigeria. The plant was identified and authenticated at Forestry Research Institute of Nigeria, Ibadan, Oyo State with voucher specimen number 112177.

\section{Extraction procedure}

Justicia secunda leaves were washed and dried in a hot air-oven at $40{ }^{\circ} \mathrm{C}$ for $48 \mathrm{~h}$. They were pulverized using a mechanical blender and sieved to obtain the fine powder form. Eighty grams of pulverized J. secunda leaves was steeped in $640 \mathrm{~mL} \mathrm{70 \%} \mathrm{methanol} \mathrm{(1:8),} \mathrm{shaken} \mathrm{intermit-}$ tently for $48 \mathrm{~h}$. The obtained suspension was filtered using Whatman No.1 filter paper and the filtrate concentrated in a rotary evaporator (Buchi Rotavapor RE-3; Buchi Labortecknic AG, Switzerland) at $40{ }^{\circ} \mathrm{C}$. The obtained concentrate yield was $8.16 \mathrm{~g}$, stored at $4{ }^{\circ} \mathrm{C}$ until further use.

\section{Evaluation of in vitro anti-inflammation activity Inhibition of heat-induced bovine serum albumin denaturation assay}

Effect of methanol extract of J. secunda leaves (MEJSL) on heat-induced bovine serum albumin (BSA) denaturation assay was carried out using a method described by Chandra et al. [20] with minor modifications. The reaction mixtures consist of varying concentrations (100, 200, 300 and $500 \mu \mathrm{g} / \mathrm{mL}$ ) of MEJSL or reference drug diclofenac sodium (2-[(2,6 dichlorophenyl)amino] benzene acetic acid sodium salt) (an NSAID), 1\% w/v BSA and phosphate buffered saline (PBS, pH 6.4) separately while PBS was used as control. The reaction mixtures were incubated at $37^{\circ} \mathrm{C}$ for $20 \mathrm{~min}$ and the temperature was increased to keep the samples at $70^{\circ} \mathrm{C}$ for $5 \mathrm{~min}$. After cooling, turbidity was measured at $660 \mathrm{~nm}$ using UV-visible spectrophotometer (Schimadzu Double Beam UV-2600, Japan). The control represents $100 \%$ protein denaturation. The percentage inhibition of BSA denaturation was calculated as stated below:

$$
\text { \%inhibition of BSA denaturation }=100 \times[1-(\mathrm{A} 2 / \mathrm{A} 1)]
$$

Where $\mathrm{A} 1=$ absorbance of the control, and A2 = absorbance of the test sample.

\section{Erythrocyte membrane stabilization assay}

The effect of MEJSL on hypotonicity-induced erythrocyte membrane hemolysis assay was performed following the method adopted by Shinde et al. [21] and modified by Oyedapo et al. [22]. Whole blood sample $(5 \mathrm{~mL})$ was obtained from human by venipuncture using a syringe and immediately transferred to an ethylenediaminetetraacetic acid (EDTA) bottle. The blood sample was centrifuged for $10 \mathrm{~min}$ at $3000 \mathrm{rpm}$ (rpm) and the supernatant was carefully removed while the packed red blood cells were washed in freshly prepared isosaline solution 
$(0.85 \% \mathrm{NaCl})$. Subsequently, the blood was washed and centrifuged repeatedly until the supernatant became clear. Stock red blood cell $(10 \% \mathrm{v} / \mathrm{v})$ was prepared in isosaline solution. The assay mixture contained $1 \mathrm{~mL}$ sodium phosphate buffer ( $\mathrm{pH} 7.4,0.15 \mathrm{~mol} / \mathrm{L}), 2 \mathrm{~mL}$ hyposaline solution $(0.36 \% \mathrm{w} / \mathrm{v} \mathrm{NaCl}), 0.5 \mathrm{~mL}$ stock red blood cell suspension $(10 \%, \mathrm{v} / \mathrm{v})$ with $0.5 \mathrm{~mL}$ of MEJSL or diclofenac sodium (reference drug) of varying concentrations in test tubes. For the control, distilled water replaced hyposaline solution to induce $100 \%$ hemolysis. The different test tubes were incubated at $56^{\circ} \mathrm{C}$ in a water bath for $30 \mathrm{~min}$ and then centrifuged at $5000 \mathrm{rpm}$. The hemoglobin content in each tube was estimated using UV-visible spectrophotometer (Schimadzu Double Beam UV-2600, Japan) at $560 \mathrm{~nm}$.

$$
\% \text { stabilization }=100-\left[\frac{\text { optical density of extract }}{\text { optical density of control }} \times 100\right]
$$

\section{Experimental animals}

Fifty (50) male albino rats (Wistar strain) weighing between 100 and $180 \mathrm{~g}$ were purchased from the Animal Facility, Babcock University. The rats were allowed to acclimatized and fed with commercial pellet rat chow and water for 14 days. The rats were housed in plastic cages and maintained following the National Institute of Health $(\mathrm{NIH})$ documentation on the guide for the care and use of laboratory animals [23].

\section{Experimental animal design}

The rats were randomly distributed into 10 groups by a feature of weight, for two separate investigations, consisting of 5 rats per group.

\section{Experiment 1: carrageenan-induced inflammation model}

Effect of MEJSL on carrageenan-induced inflammation was carried out as described by Winter et al. [24]. This experiment involved five groups of five rats each, the rats were fasted overnight and had free access to water prior to the day of the experiment. The experimental design was as follows: Group I: rats were orally administered with $1 \mathrm{~mL} 0.9 \% \mathrm{NaCl}$ only (normal group); Group II: rats were orally administered with $1 \mathrm{~mL} 0.9 \% \mathrm{NaCl}+$ induction of arthritis using carrageenan (control group); Group III: rats were orally administered with $10 \mathrm{mg} / \mathrm{kg}$ body weight (b.w.) diclofenac sodium + induction of arthritis using carrageenan (standard group); Group IV and V: rats were orally administered with 100 and 300 $\mathrm{mg} / \mathrm{kg}$ b.w. MEJSL + induction of arthritis using carrageenan (test groups). Prior to the treatments, the initial paw edema of each rat was measured using a micrometer screw gauge. One hour after treatment, paw edema was induced by injecting $0.1 \mathrm{~mL} 1 \%$ solution of carrageenan into the left hind paw just beneath the plantar of aponeurosis. Subsequently, the increase in left paw edema was measured at an hour interval for $6 \mathrm{~h}$ posttreatment. The percentage inhibition of inflammation was calculated as stated below:

$$
\text { \%inhibition of inflammation }=\left(1-\frac{V t}{V c}\right) \times 100
$$

$V t$ is the mean paw edema in the treated groups while $V t$ is the mean paw edema in the control group.

Experiment 2: formaldehyde-induced inflammation model Effect of MEJSL on formaldehyde-induced inflammation assay was carried out by following a modified method described by Agnel and Shobana [25]. The study involved five groups of five rats each, the rats were fasted overnight and had free access to water prior to the day of the experiment which lasted for 7 days. The experimental design was as follows: Group I: rats were orally administered with $0.2 \mathrm{~mL} 0.9 \% \mathrm{NaCl}$ only (normal group); Group II: rats were orally administered with $0.2 \mathrm{~mL} 0.9 \% \mathrm{NaCl}+$ induction of arthritis using 2\% v/v formaldehyde (control group); Group III: rats were orally administered with 10 $\mathrm{mg} / \mathrm{kg}$ b.w. diclofenac sodium + induction of arthritis using $2 \% \mathrm{v} / \mathrm{v}$ formaldehyde (standard group); Group IV and V: rats were orally administered with 100 and 300 $\mathrm{mg} / \mathrm{kg}$ b.w. MEJSL + induction of arthritis using $2 \% \mathrm{v} / \mathrm{v}$ formaldehyde (test groups). In the first and third days of treatment, $0.02 \mathrm{~mL} 2 \% \mathrm{v} / \mathrm{v}$ formaldehyde was injected into the left hind paw of rats just beneath the plantar of aponeurosis to induce arthritis. The increase in paw edema was measured using a micrometer screw gauge. This was done $30 \mathrm{~min}$ before the induction of arthritis, and every $24 \mathrm{~h}$ for 7 days. The percentage inhibition of inflammation was calculated as stated below:

$$
\text { \%inhibition of inflammation }=\left(1-\frac{V t}{V c}\right) \times 100
$$

$V t$ is the mean paw edema in the treated groups while $V t$ is the mean paw edema in the control group.

\section{Biochemical assays}

On the eight-day of the formaldehyde-induced inflammation model study, blood samples were collected by using $5 \mathrm{~mL}$ hypodermal syringes through cardiac puncture and transferred into EDTA bottles and heparin bottles to avoid clotting. The whole blood samples in heparin bottles were spun in a centrifuge (UNICO C856 Power $\operatorname{Spin}^{\mathrm{Tm}}$ Model LX, United States) at $3500 \mathrm{rpm}$ for 5 min to obtain plasma which was used for liver and kidney function analysis while blood samples in EDTA bottles were used for hematological analysis. 


\section{Liver function analysis}

Effect of MEJSL on aspartate aminotransferase (AST) and alanine aminotransferase (ALT) activities were assayed according to the method outlined in the Randox kit (Randox, United Kingdom).

\section{Kidney function analysis}

Effect of MEJSL on plasma creatinine and urea concentrations were measured following the quantitative colorimetric methods as outlined in the Randox kit (Randox, United Kingdom).

\section{Hematological analysis}

Hematological analysis was performed using whole blood samples in EDTA bottles to determine red blood cell (RBC), hematocrit (HCT), hemoglobin (HGB), platelet (PLT), white blood cell (WBC), lymphocyte (LYM), granulocyte (GRAN), basophil, eosinophil, and monocyte (EBM) counts using an autoanalyzer (Swelab Alfa 3-Part Hematology Analyzer, Boule Medicals, Spanga, Sweden) at Babcock University Teaching Hospital Medical Laboratory.

\section{Statistical analysis}

Data were expressed as mean \pm standard error of mean (SEM) $(n=5)$. Sample T-test analytical method was used to evaluate the difference between means in the in vitro anti-inflammatory experiments. Linear regression was performed to determine $50 \%$ inhibitory concentration $\left(\mathrm{IC}_{50}\right)$. The difference between the experimental and control groups was determined using GraphPad Prism ${ }^{\circ}$ version 7.0, the comparison carried out using one-way analysis of variance (ANOVA). The significant difference in the experimental groups was assessed using the least significant difference (LSD) post-hoc analysis to test the significance at $P<0.05$.

\section{Results}

In vitro anti-inflammation assays

Data in Table 1 showed that $100-500 \mu \mathrm{g} / \mathrm{mL}$ MEJSL and diclofenac sodium inhibited heat-induced BSA denaturation in a concentration-dependent manner. MEJSL $\quad\left(\mathrm{IC}_{50}=186.20 \pm 2.25 \mu \mathrm{g} / \mathrm{mL}\right)$ significantly $(P<$ $0.05)$ exhibited a higher inhibition of heat-induced BSA denaturation than diclofenac sodium $\left(\mathrm{IC}_{50}=\right.$ $215.50 \pm 4.11 \mu \mathrm{g} / \mathrm{mL}$ ). Furthermore, Data in Table 2 showed that the $250-2000 \mu \mathrm{g} / \mathrm{mL}$ MEJSL and diclofenac sodium stabilized erythrocyte membrane against hypotonicity-induced hemolysis in a concentrationdependent manner. The MEJSL $(480.40 \pm 1.47 \mu \mathrm{g} / \mathrm{mL})$ significantly $(P<0.05)$ stabilized erythrocyte membrane against hypotonicity-induced hemolysis than diclofenac sodium $(637.40 \pm 2.69 \mu \mathrm{g} / \mathrm{mL})$.

\section{In vivo anti-inflammation assays}

\section{Carrageenan-induced inflammation model}

Data in Fig. 1 showed that 100 and $300 \mathrm{mg} / \mathrm{kg}$ b.w. $\mu \mathrm{g} /$ $\mathrm{mL}$ MEJSL and $10 \mathrm{mg} / \mathrm{kg}$ b.w. diclofenac sodium treated animals induced with inflammation using carrageenan significantly $(P<0.05)$ inhibited paw edema in a dosedependent manner when compared with the untreated control group for a period of 6 hours. Diclofenac sodium $(10 \mathrm{mg} / \mathrm{kg}$ b.w.), 100 and $300 \mathrm{mg} / \mathrm{kg}$ b.w. MEJSL suppressed paw edema of rats at the sixth hour by $0.58 \pm$ $0.03 \mathrm{~mm}(71.14 \%), 0.34 \pm 0.09 \mathrm{~mm}(83.08 \%)$ and $0.22 \pm$ $0.07 \mathrm{~mm}(89.05 \%)$, respectively when compared with those of untreated control group.

\section{Formaldehyde-induced inflammation model}

Data in Fig. 2 indicated that orally administered 100 and $300 \mathrm{mg} / \mathrm{kg}$ b.w. MEJSL and $10 \mathrm{mg} / \mathrm{kg}$ b.w. diclofenac sodium to experimental animals induced with inflammation using $2 \% \mathrm{v} / \mathrm{v}$ formaldehyde significantly $(P<0.05)$ inhibited paw edema of rats when compared with the untreated control group in a dose-dependent manner. The 100 and $300 \mathrm{mg} / \mathrm{kg}$ b.w. MEJSL suppressed paw edema of rats by $74.73 \%(1.15 \pm 0.30 \mathrm{~mm})$ and $76.48 \%$ $(1.07 \pm 0.40 \mathrm{~mm})$ which was found to be comparable with the animals treated with $10 \mathrm{mg} / \mathrm{kg}$ b.w. diclofenac sodium that inhibited paw edema by $75.53 \%(1.25 \pm 0.33$ $\mathrm{mm})$, respectively.

Table 1 Effect of methanol extract of $J$. secunda leaves on heat-induced BSA denaturation

\begin{tabular}{llll}
\hline Test samples & Concentration $(\mu \mathrm{g} / \mathrm{mL})$ & Inhibition $(\%)$ & $\mathrm{I} C_{50}(\mu \mathrm{g} / \mathrm{mL})$ \\
\hline Methanol extract of J. secunda leaves & 100 & $25.00 \pm 0.01$ & $32.73 \pm 0.01$ \\
& 200 & $36.21 \pm 0.01$ \\
& 300 & $37.71 \pm 0.03$ & $2.20 \pm 2.25$ \\
Diclofenac sodium & 500 & $2.70 \pm 0.05$ & $18.57 \pm 0.01$ \\
& 100 & $40.35 \pm 0.05$ & $215.50 \pm 4.11$ \\
\hline
\end{tabular}

Data were expressed as mean \pm SEM 
Table 2 Effect of methanol extract of J. secunda leaves on hypotonicity-induced hemolysis erythrocyte membrane

\begin{tabular}{llll}
\hline Test samples & $\begin{array}{l}\text { Concentration } \\
(\mu \mathrm{g} / \mathrm{mL})\end{array}$ & Stabilization (\%) & $\mathrm{IC} 50(\mu \mathrm{g} / \mathrm{mL})$ \\
\hline Methanol extract of J. secunda leaves & 250 & $89.98 \pm 0.03$ & $980.40 \pm 1.47$ \\
& 500 & $93.65 \pm 0.03$ & $94.56 \pm 0.01$ \\
Diclofenac sodium & 1000 & $94.45 \pm 0.03$ & $89.60 \pm 0.03$ \\
& 2000 & $91.94 \pm 0.01$ & $937.40 \pm 2.69$ \\
& 250 & $93.57 \pm 0.01$ & $95.26 \pm 0.01$
\end{tabular}

The data expressed were expressed as mean value \pm standard error of mean (SEM)

$I C_{50} 50 \%$ inhibitory concentration

\section{Liver function analysis}

\section{Plasma alanine aminotransferase (ALT) activity}

Data in Fig. 3 showed that untreated control animals $(10.24 \pm 0.55 \mathrm{U} / \mathrm{l})$ had a significantly $(P<0.05)$ elevated plasma ALT activity when compared with the normal group $(7.37 \pm 0.48 \mathrm{U} / \mathrm{l})$. Animals induced with inflammation using formaldehyde and treated with $100 \mathrm{mg} / \mathrm{kg}$ b.w. MEJSL $(8.84 \pm 0.37 \mathrm{U} / \mathrm{l}), 300 \mathrm{mg} / \mathrm{kg}$ b.w. MEJSL $(7.94 \pm 0.44 \mathrm{U} / \mathrm{l})$, and diclofenac sodium $(7.40 \pm 0.28 \mathrm{U} / \mathrm{l})$ had significantly $(P<0.05)$ reduced plasma ALT activity when compared with those of untreated group (10.24 \pm $0.55 \mathrm{U} / \mathrm{l})$. The MEJSL exhibited a dose-dependent reduction in plasma ALT activity. In addition, the plasma
ALT activity in animals treated with $300 \mathrm{mg} / \mathrm{kg}$ b.w. MEJSL was comparable to those of diclofenac treated group.

\section{Plasma aspartate aminotransferase (AST) activity}

Data in Fig. 4 showed that animals induced with inflammation using formaldehyde and treated with $100 \mathrm{mg} / \mathrm{kg}$ b.w. MEJSL $(27.10 \pm 2.31 \mathrm{U} / \mathrm{l}), 300 \mathrm{mg} / \mathrm{kg}$ b.w. MEJSL $(22.40 \pm 0.73 \mathrm{U} / \mathrm{l})$ and $10 \mathrm{mg} / \mathrm{kg}$ diclofenac sodium $(30.98 \pm 2.68 \mathrm{U} / \mathrm{l})$ had significantly $(P<0.05)$ reduced plasma AST activities when compared with untreated animals $(52.55 \pm 3.41 \mathrm{U} / \mathrm{l})$. Furthermore, MEJSL exhibited a dose-dependent decrease in plasma AST activity. Animals

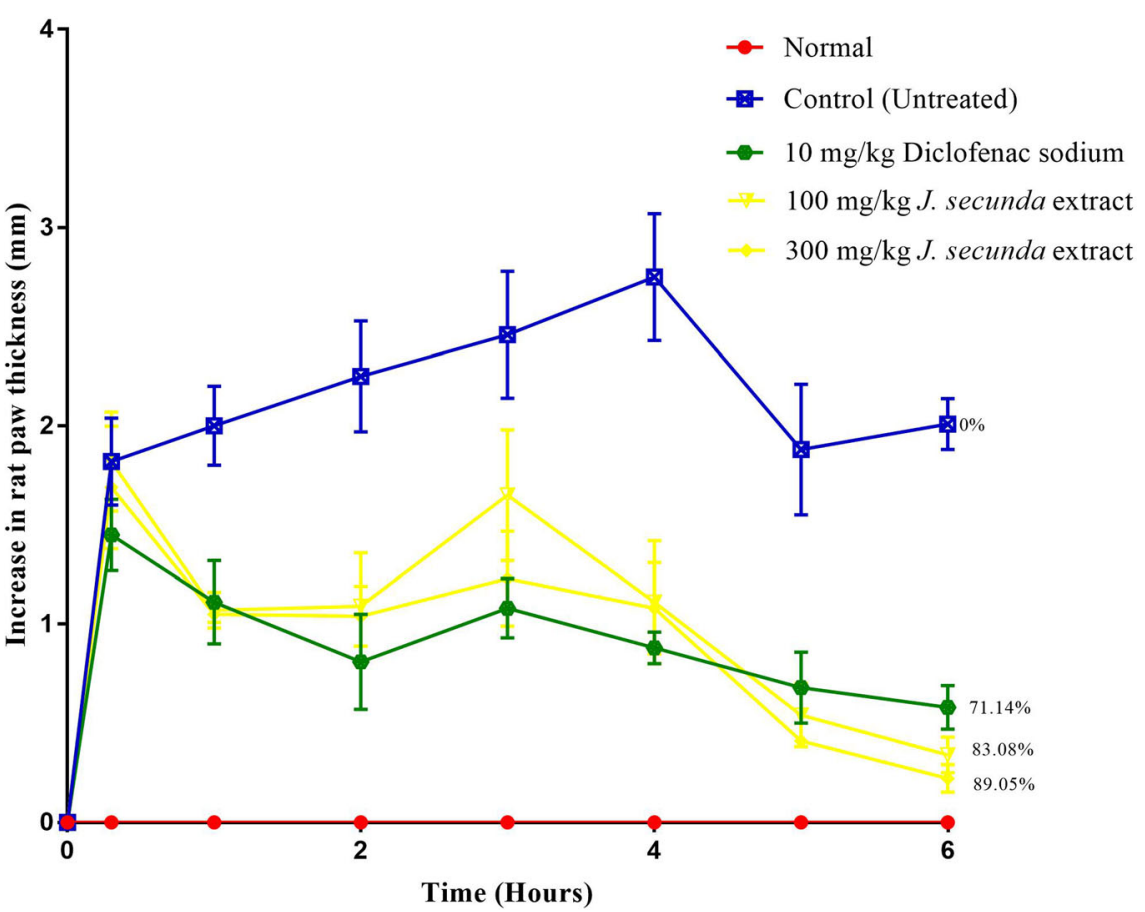

Fig. 1 Percentage inhibition of carrageenan-induced paw edema in rats treated with 100 and 300 mg/kg methanol extract of Justicia secunda leaves. Data expressed as mean \pm standard error of mean 


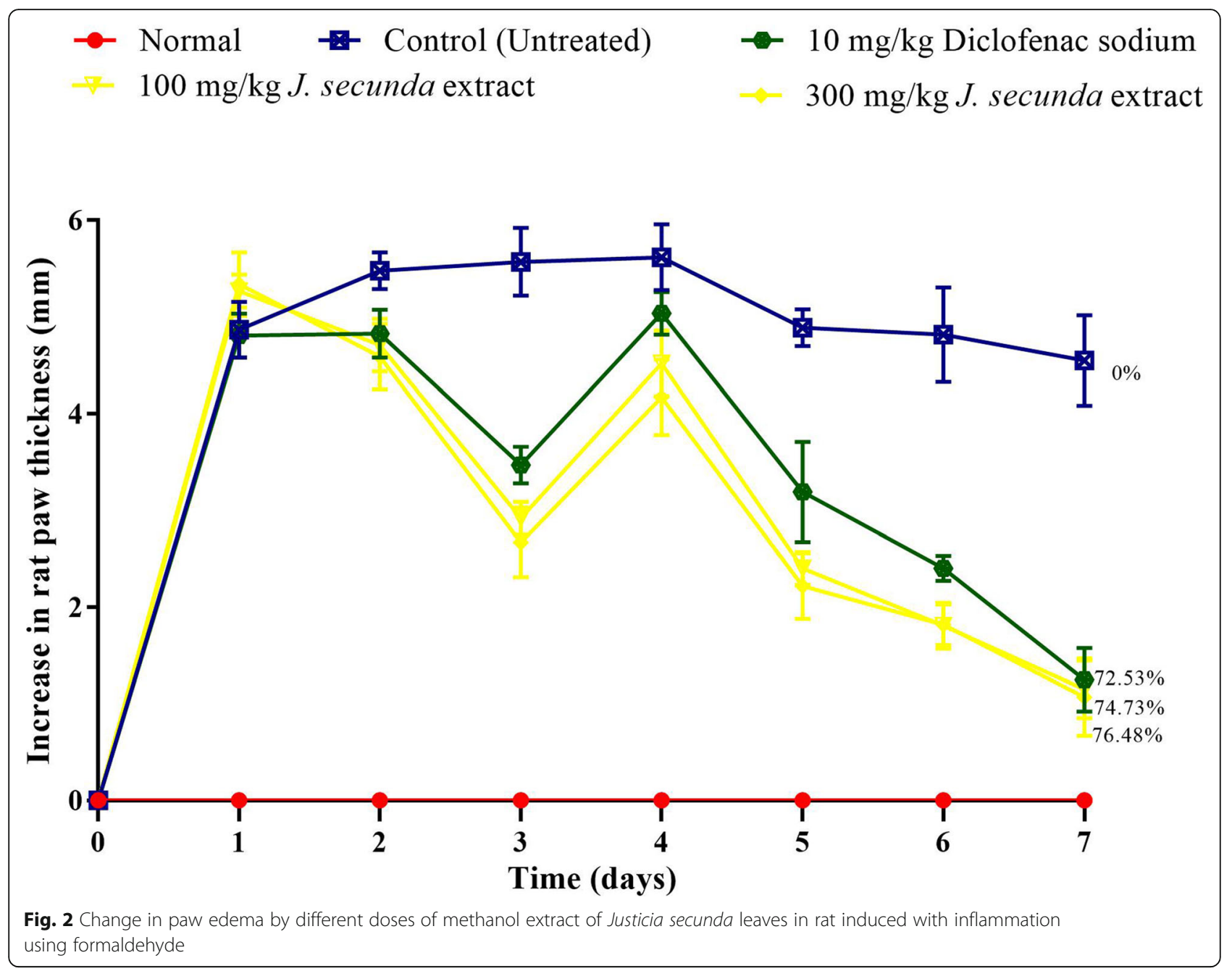

treated with $300 \mathrm{mg} / \mathrm{kg}$ b.w. MEJSL $(22.40 \pm 0.73 \mathrm{U} / \mathrm{l}) \mathrm{had}$ a significantly $(P<0.05)$ reduced plasma AST activity when compared with diclofenac sodium treated group $(30.98 \pm 2.68 \mathrm{U} / \mathrm{l})$.

\section{Kidney function analysis \\ Plasma urea}

Data in Fig. 5 showed that the untreated control group $(40.40 \pm 2.50 \mathrm{mg} / \mathrm{dL})$ had a significantly $(P<0.05)$ higher plasma urea concentration when compared with the normal group $(29.23 \pm 2.54 \mathrm{mg} / \mathrm{dL})$. Animals induced with inflammation using formaldehyde and treated with $100 \mathrm{mg} / \mathrm{kg}$ b.w. MEJSL $(25.24 \pm 2.14 \mathrm{mg} / \mathrm{dL}), 300 \mathrm{mg} / \mathrm{kg}$ b.w. MEJSL $(26.12 \pm 0.98 \mathrm{mg} / \mathrm{dL})$ and $10 \mathrm{mg} / \mathrm{kg}$ b.w. diclofenac sodium $(30.9 \pm 1.68 \mathrm{mg} / \mathrm{dL})$ had significantly $(P<0.05)$ decreased plasma urea concentrations when compared with the untreated control group. Furthermore, animals treated with MEJSL had significantly $(P<$ $0.05)$ reduced plasma urea concentration when compared with diclofenac sodium treated group.

\section{Plasma creatinine}

Figure 6 showed that the untreated control group (1.62 \pm $0.22 \mathrm{mg} / \mathrm{dL})$ had a significantly $(P<0.05)$ elevated plasma creatinine concentration when compared with the normal group $(0.95 \pm 1.10 \mathrm{mg} / \mathrm{dL})$. However, animals induced with inflammation using formaldehyde and treated with 100 $\mathrm{mg} / \mathrm{kg}$ b.w. MEJSL $(1.33 \pm 0.13 \mathrm{mg} / \mathrm{dL}), 300 \mathrm{mg} / \mathrm{kg}$ b.w. MEJSL $(1.08 \pm 0.06 \mathrm{mg} / \mathrm{dL})$ and $10 \mathrm{mg} / \mathrm{kg}$ b.w. diclofenac sodium $(1.04 \pm 0.13 \mathrm{mg} / \mathrm{dL})$. The MEJSL treated animals exhibited a dose-dependent reduction in plasma creatinine concentrations. The $300 \mathrm{mg} / \mathrm{kg}$ b.w. MEJSL treated animals had comparable plasma creatinine concentration when compared with diclofenac sodium treated animals.

\section{Hematological analysis}

Results in Table 3 indicated that 100 and $300 \mathrm{mg} / \mathrm{kg}$ b.w. MEJSL treated animals induced with inflammation using formaldehyde had significantly $(P<0.05)$ higher red blood cell (RBC), hematocrit (HCT), hemoglobin (HGB) and platelet (PLT) counts when compared with the untreated control group. However, there was no significant 


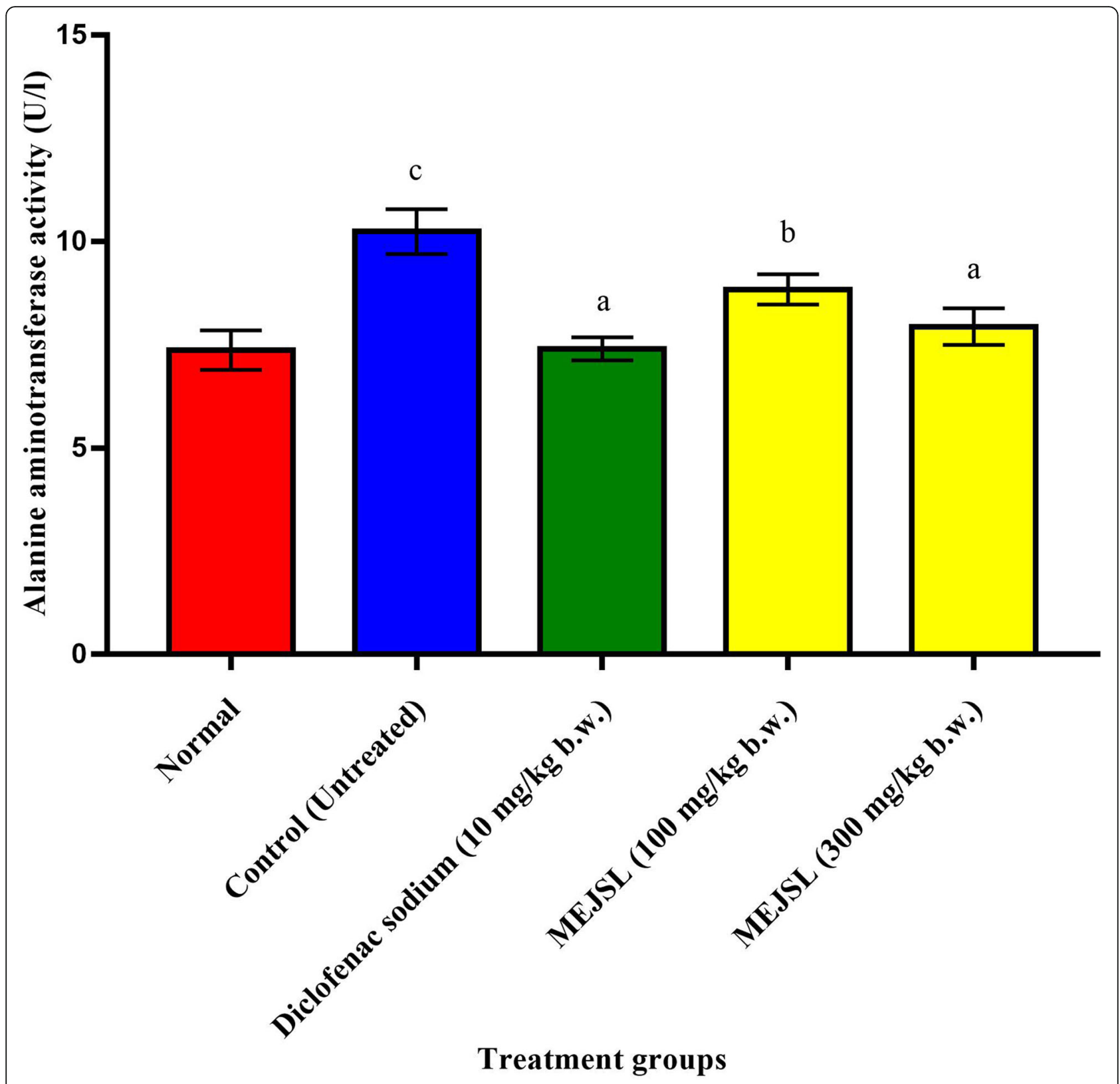

Fig. 3 Effects of methanol extract of J. secunda leaves on plasma alanine aminotransferase (ALT) activity in normal and formaldehyde-induced arthritic rats. MEJSL-indicates methanol extract of Justicia secunda leaves. Different letters indicate significantly different at $P<0.05$

difference $(P>0.05)$ in RBC, HCT, HGB and PLT counts between $10 \mathrm{mg} / \mathrm{kg}$ b.w. diclofenac sodium treated animals and untreated control group. Furthermore, 100 and $300 \mathrm{mg} / \mathrm{kg}$ b.w. MEJSL treated animals had significantly $(P<0.05)$ reduced white blood cell (WBC), lymphocyte (LYM), granulocyte (GRAN), eosinophil, basophil and monocyte (EBM) counts when compared with untreated control animal. However, WBC, LYM, GRAN and EBM counts in animals treated with diclofenac sodium were not significantly different $(P>0.05)$ when compared with untreated control animals.

\section{Discussion}

Identification and isolation of medicinal products from plants have been an ever-increasing area of interest in the field of drug discovery [26]. In this present study, the anti-inflammatory potential of methanol extract of $J$. secunda leaves (MEJSL) using in vitro and in vivo inflammation models were evaluated.

The different concentrations of MEJSL exhibited high inhibition of heat-induced protein denaturation and stabilization of erythrocyte membrane against hypotonicityinduced hemolysis, when compared with those of 


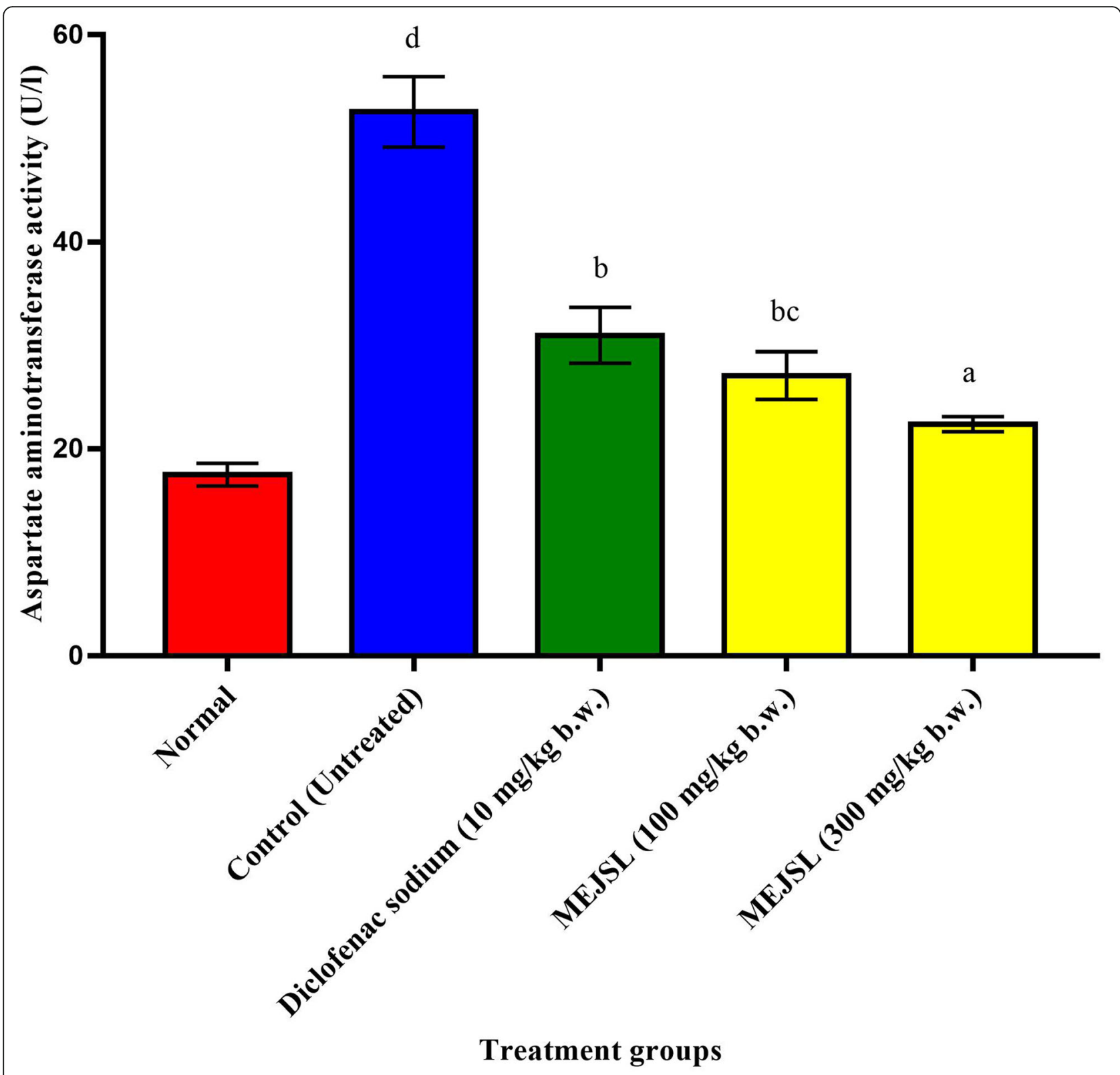

Fig. 4 Effects of methanol extract of J. secunda leaves on the plasma aspartate aminotransferase (AST) activity in normal and formaldehydeinduced arthritic rats. MEJSL-indicates methanol extract of Justicia secunda leaves. Different letters indicate significantly different at $P<0.05$

diclofenac sodium. These data indicate that MEJSL could contain an anti-inflammatory property. Previous studies have demonstrated that plant extracts with antiinflammatory property possess the capacity to inhibit protein denaturation and stabilize cell membrane against lysis $[27,28]$. Protein denaturation is a biochemical reaction that occurs during chronic inflammatory response which could result into loss of tissue function [29, 30]. In addition, lysis of lysosomal membranes during chronic inflammation has been proven to release pro-inflammatory markers including activated neutrophils, proteases and histamines at the local site of tissue damage [31, 32]. Hence, medicinal plant extract that inhibit protein denaturation and stabilize cell membrane against lysis could serve as a potential source of lead anti-inflammatory drug candidates.

Furthermore, the in vivo anti-inflammatory potential of MEJSL was evaluated using two animal models: carrageenan and formaldehyde induced inflammations. In carrageenan and formaldehyde-induced inflammation models, the animals that were orally administered with 100 and $300 \mathrm{mg} / \mathrm{kg}$ b.w. MEJSL had substantially suppressed paw edema thickness when compared with those of untreated control animals. This indicates that MEJSL possesses anti-inflammatory activity in vivo. 


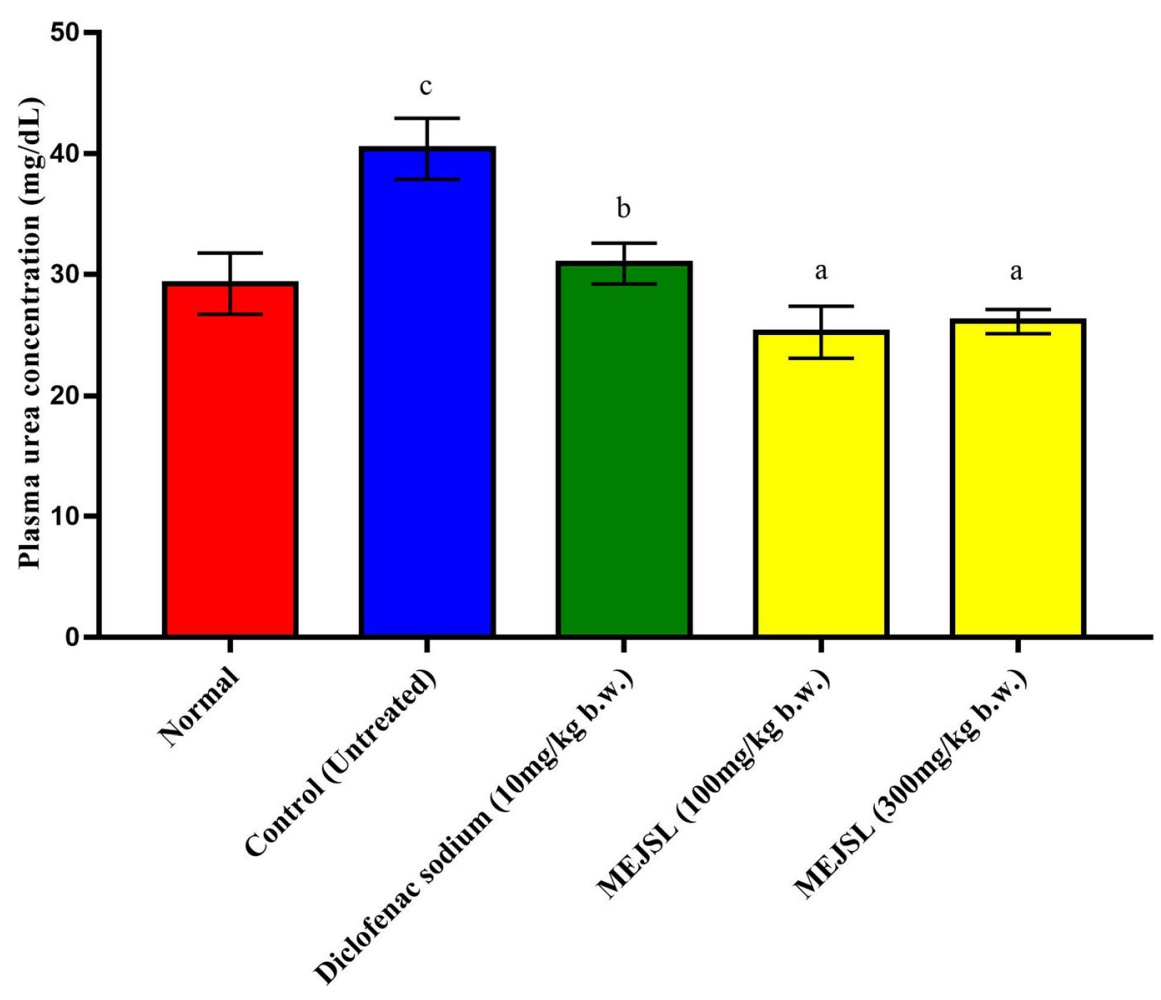

Treatment groups

Fig. 5 Effects of methanol extract of $J$. secunda leaves on the concentration of plasma urea in normal and formaldehyde-induced treated rats. MEJSL-indicates methanol extract of Justicia secunda leaves. Different letters indicate significantly different at $P<0.05$

These findings supported the data from the in vitro anti-inflammatory study that purported MEJSL to possess anti-inflammatory property. Previously, it has been documented that carrageenan and formaldehyde are agents that have the capacity to elicit the release of inflammatory stressors including prostaglandin, serotonin, protease, lysosome, cytokine, and histamine in animal models [15]. Hence, it is suggested that the capacity of MEJSL to suppress rat paw edema in carrageenan and formaldehyde induced inflammation rat models might be through mitigation of the release and migration of inflammatory stressors to the site of tissue damage. Furthermore, bioactive compounds present in MEJSL could be responsible for the anti-inflammatory action. Previous studies reported that J. secunda leaves contain polyphenolic compounds, which have been shown to potentially exhibit anti-inflammatory effects $[5,8,33]$.

In addition, the anti-inflammatory property of MEJSL in the animal models might be through activation of nuclear factor-erythroid 2 p 45 related factor 2 (Nrf2) signaling pathway. Several studies have demonstrated that Nrf2 signaling pathway is a key target in the discovery of anti-inflammatory bioactive compounds. Nrf2 orchestrates the activation of anti-inflammatory and antioxidant gene expressions through the Keap (Kelch- like $\mathrm{ECH}$-associated protein) 1/Nrf2/ARE (antioxidant response element) signaling pathway and inhibits the progression of inflammation, thereby protecting cells from injuries $[34,35]$. A supplementation with hydroxytyrosol, a polyphenolic compound had been shown to reduce the inflammatory stressors in mice fed with high fat diet through activation of Nrf2 pathway and downregulation of nuclear factor kappa $\mathrm{B}(\mathrm{NF}-\mathrm{kB})[36,37]$. $\mathrm{NF}-\mathrm{kB}$ has been shown to induce transcription of proinflammatory mediators which includes interleukins, cytokines and cyclooxygenase-2 (COX-2) [38]. Hence, plant bioactive compound that target and inhibit NF- $\mathrm{KB}$ could serve as anti-inflammatory agent. More so, a plant polyphenol, kaempferol has been demonstrated to attenuate interleukin (IL)-6-induced COX-2 expression in human monocytic THP-1 cells suggesting its beneficial role in chronic inflammation [39].

In this present study, experimental animals induced with inflammation using carrageenan and formaldehyde models were found to exhibit a biphasic inflammatory response to tissue damage. Previous studies stipulate that the first phase of inflammatory response in carrageenan-induced inflammation is usually due to the release of substance P, kininlike substances, serotonin and histamine with enhanced production of prostaglandins at the localized site of tissue 


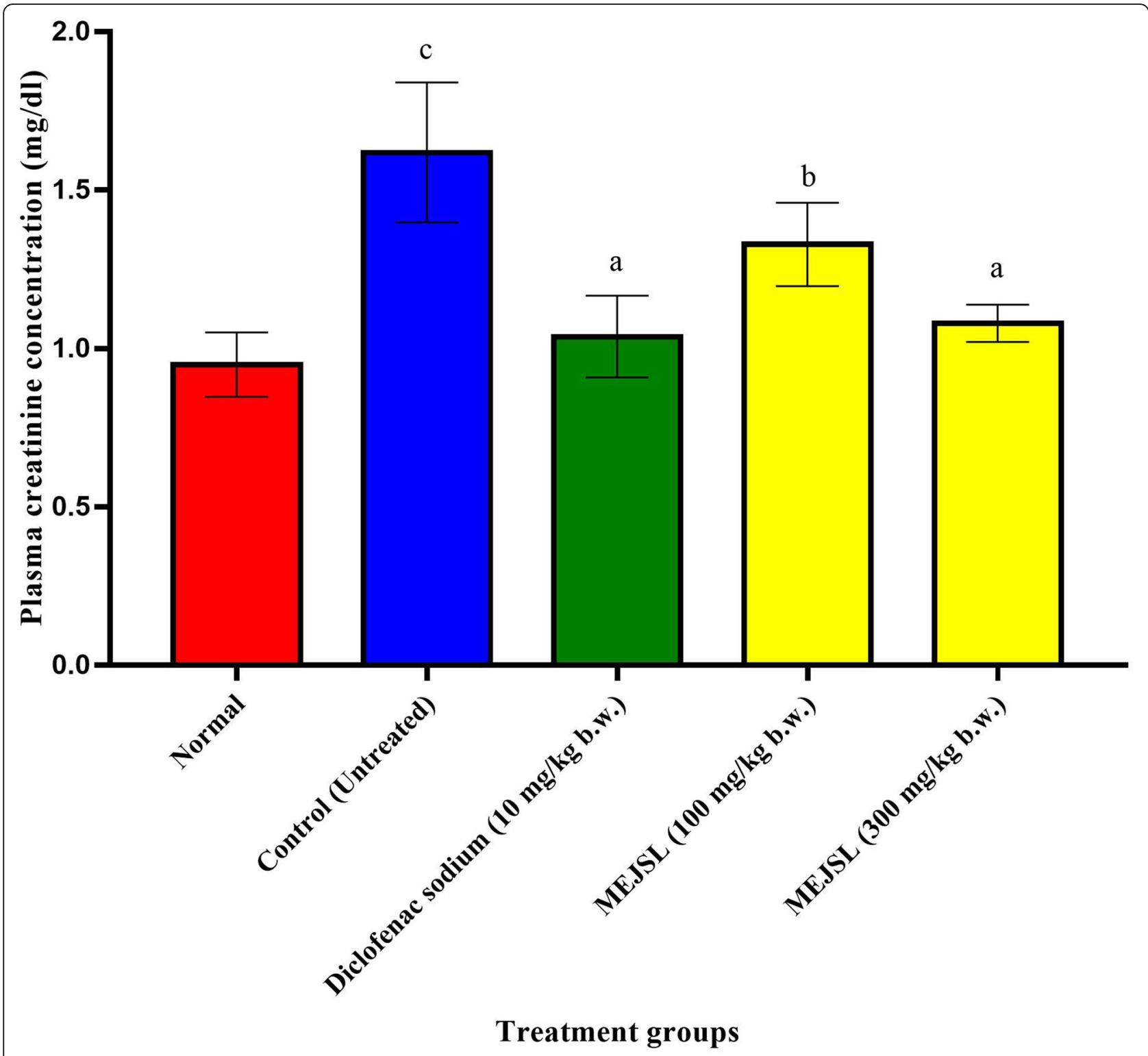

Fig. 6 Effects of methanol extract of J. secunda leaves on plasma creatinine concentration in normal and formaldehyde-induced arthritic rats. MEJSL-indicates methanol extract of Justicia secunda leaves. Different letters indicate significantly different at $P<0.05$

damage within $2 \mathrm{~h}$, while the second inflammation phase is characterized by the release of bradykinin, leukotrienes, prostaglandins, and proteases [40]. Based on this premise, it can be deduced from the carrageenan-induced inflammation model that suppression of the first inflammatory phase at 2nd hour by MEJSL might be due to inhibition of early pro-inflammatory mediator's release, including histamine and serotonin. The suppressive effect noted during second inflammatory phase might be the resultant effect of cyclooxygenase inhibition by MEJSL [41]. It was also thought that the membrane-stabilizing property of MEJSL could prevent the release of proteases from lysosomes, thereby mitigating the release of pro-inflammatory factors.
Furthermore, the biphasic phenomenon in formaldehyde-induced inflammation model has been reported to be both neurogenic (first phase) and antiinflammatory (second phase) [40]. MEJSL suppressed paw edema starting from the 2nd day of animal treatment. This further strengthens the claim that MEJSL possesses anti-inflammatory property. Previous studies have shown that the first phase of an inflammatory response results from the stimulation of pain receptors and it is usually insensitive to anti-inflammatory agents. This could account for the increase in rat paw thickness in all experimental groups from the time of treatment until "day 2" when suppression was noticed among the 
Table 3 Effects of methanol extract of J. secunda leaves on hematological parameters of rats induced with inflammation using formaldehyde

\begin{tabular}{llllll}
\hline Parameters & Normal & Untreated control & $10 \mathrm{mg} / \mathrm{kg}$ b.w. Diclofenac sodium & $\begin{array}{l}100 \mathrm{mg} / \mathrm{kg} \text { b.w. } \\
\text { MEJSL }\end{array}$ & $\begin{array}{l}300 \mathrm{mg} / \mathrm{kg} \mathrm{b} . \mathrm{w} . \\
\text { MEJSL }\end{array}$ \\
\hline RBC $\left(10^{12} / \mathrm{L}\right)$ & $6.43 \pm 0.69$ & $6.19 \pm 0.04^{\alpha}$ & $6.16 \pm 0.75^{\alpha}$ & $7.09 \pm 0.53^{\beta}$ & $7.87 \pm 0.10^{\beta}$ \\
HCT $(\%)$ & $41.96 \pm 5.84$ & $38.30 \pm 1.42^{\alpha}$ & $40.60 \pm 1.13^{\alpha}$ & $42.14 \pm 1.09^{\beta}$ & $44.92 \pm 1.31^{\beta}$ \\
HGB $(\mathrm{g} / \mathrm{dl})$ & $13.50 \pm 1.07$ & $12.36 \pm 0.94^{\alpha}$ & $12.56 \pm 0.31^{\alpha}$ & $14.36 \pm 0.87^{\beta}$ & $14.66 \pm 0.36^{\beta}$ \\
PLT $\left(10^{9} / \mathrm{L}\right)$ & $489.00 \pm 67.32$ & $339.40 \pm 72.58^{\alpha}$ & $335.20 \pm 83.65^{a}$ & $527.80 \pm 48.36^{\beta}$ & $619.40 \pm 36.44^{\beta}$ \\
WBC $\left(10^{9} / \mathrm{L}\right)$ & $9.22 \pm 3.26$ & $11.18 \pm 0.12^{\Omega}$ & $9.66 \pm 0.16^{\epsilon}$ & $9.04 \pm 0.26^{*}$ & $8.46 \pm 1.53^{*}$ \\
LYM $\left(10^{9} / \mathrm{L}\right)$ & $7.06 \pm 2.11$ & $8.25 \pm 0.99^{\Omega}$ & $7.50 \pm 1.63^{\epsilon}$ & $7.40 \pm 0.78^{*}$ & $7.10 \pm 1.39^{*}$ \\
GRAN $\left(10^{9} / \mathrm{L}\right)$ & $1.40 \pm 0.85$ & $0.74 \pm 0.12^{\Omega}$ & $0.84 \pm 0.21^{\epsilon}$ & $0.62 \pm 0.06^{*}$ & $0.44 \pm 0.07^{*}$ \\
EBM $\left(10^{9} / \mathrm{L}\right)$ & $0.76 \pm 0.32$ & $2.79 \pm 0.10^{\Omega}$ & $1.32 \pm 0.35^{\epsilon}$ & $1.02 \pm 0.15^{*}$ & $0.92 \pm 0.13^{*}$ \\
\hline
\end{tabular}

$R B C$ red blood cells, $H C T$ hematocrit, $P L T$ platelet, WBC white blood cells, HGB hemoglobin, $L Y M$ lymphocytes, GRAN granulocytes, EBM eosinophil, basophil, and monocyte, MEJSL methanol extract of Justicia secunda leaves

Different symbols across row indicate significantly different at $P<0.05$

MEJSL and diclofenac sodium treated groups. More so, anti-inflammatory agents have been demonstrated to prominently block the second phase than the first phase in formaldehyde-induced inflammation model [42, 43]. The second phase of an inflammatory response is dependent on peripheral inflammation due to changes in the pain receptors by chemical mediators including prostaglandin-like substances [40]. Hence, evidence from this present study suggests that MEJSL may be suppressing the chemical mediators associated with inflammation. This data seems to be in agreement with the previous claim that $J$. secunda leaves could possess an anti-inflammatory activity [5].

Furthermore, MEJSL treated animals had reduced plasma AST and ALT activities when compared with untreated control animals. This revealed that MEJSL could possess hepatoprotective effect. It has been previously shown that elevated plasma AST and ALT activities are indicators of tissue damage which are measured clinically as a diagnostic evaluation of liver function [44]. Hepatocellular damage resulting from formaldehyde-induced oxidative and inflammatory stressors could cause leakage of cytoplasmic enzymes into the plasma with concomitant increase in plasma enzyme activities. This observed hepatoprotective effect of MEJSL might be due to the presence of bioactive compounds with antioxidant activity against ROS-induced tissue damage. Previous data had shown that $J$. secunda leaves possess antioxidant compounds [5]. It could also be due to the presence of electrophilic compounds in $J$. secunda leaves that activate Nrf2 signaling pathway. The activated Nrf2 is translocated to the nucleus where it transactivate ARE which in turn triggers the upregulation of cytoprotective antioxidant and drug detoxifying genes, thereby protecting tissues against oxidative and inflammatory stressors [34].

Furthermore, animals treated with MEJSL had reduced plasma urea and creatinine concentrations when compared with untreated control animals. The reduced plasma urea and creatinine concentrations could be indicative of MEJSL nephroprotective activity. Plasma urea and creatinine concentrations are measured primarily to assess kidney function where their elevation is indicative of under-excretion capacity of the kidney, suggesting kidney impairment [45]. Hence, findings from this present study connotes that MEJSL contains bioactive compounds with nephroprotective property. Previous report has also shown that plant polyphenols could elicit a chemoprotective effect against kidney damage [46].

Hematological analysis revealed that animals induced with inflammation using formaldehyde and treated with 100 and $300 \mathrm{mg} / \mathrm{kg}$ b.w. MEJSL had elevated RBC, HCT, and HGB counts when compared with the untreated control and normal groups. This suggests that MEJSL could possess erythropoietic property. Previous study had indicated the $J$. secunda leaves could contain blood-boosting principles and this perhaps account for its ethnobotanical use in the management of anemia [5, 8]. In addition, the elevated platelet count in the MEJSL treated animals could be indicative of its wound healing property. Platelet cells had been demonstrated to play a major role in the healing process of damaged tissues [47].

Further investigation showed that animals treated with MEJSL and diclofenac sodium had reduced WBC, LYM, GRAN, and EBM counts when compared with untreated control animals. This suggests that MEJSL could possess immunomodulatory activity. An elevation in the immunological/inflammatory cells has been reported to indicate a heightened inflammatory response to the local site of tissue damage $[15,48]$. More so, cellular response played by infiltrating cells through the release lysosomal contents at the local site of tissue damage would aggravate the inflammatory stressors $[49,50]$. During inflammation, immunological/inflammatory cells generate ROS that damage macromolecules and also produce large 
amount of pro-inflammatory mediators including cytokines, chemokines and prostaglandins. These proinflammatory markers further recruit macrophages and directly activate multiple signal transduction cascades and transcription factors such as NF- $\mathrm{kB}$, MAPK (mitogen-activated protein kinase), and JAK (janus kinase)STAT (signal transducers and activators of transcription) associated with inflammation signaling pathways [15]. The clinical use of non-steroidal anti-inflammatory drugs have also been reported to exhibit immunomodulatory activity on infiltrating cells at the local site of tissue damage [51].

\section{Conclusions}

This study suggested that the methanol extract of $J$. secunda leaves possess anti-inflammatory, hepatoprotective, nephroprotective and immunomodulatory activities. It also showed that the anti-inflammatory mechanisms of action might be through direct inhibition of phase 2 pro-inflammatory signals, activation of Nrf2 signaling pathways, upregulation of cytoprotective genes and stabilization of inflammatory cell membranes. Furthermore, it provides some scientific insight into the ethnobotanical use of $J$. secunda leaves in folklore medicine. It is recommended that MEJSL could be considered as a choice candidate in pharmaceutical anti-inflammatory drug development.

\section{Abbreviations \\ ALT: Alanine aminotransferase; ARE: antioxidant response elemen; AST: Aspartate aminotransferase; COX: Cyclooxygenase; EBM: Eosinophil, Basophil and Monocyte; GRAN: Granulocyte; HCT: Hematocrit; HGB: Hemoglobin; JAK: Janus kinase; Keap1: Kelch-like ECH-associated protein 1; LYM: Lymphocyte; MAPK: mitogen-activated protein kinase; MEJSL: Methanol extract of Justicia secunda leaves; NF-KB: Nuclear factor kappa B; Nrf2: Nuclear factor-erythroid 2 p45 related factor 2; NSAID: Non- steroidal anti-inflammatory drugs; PLT: Platelet; RBC: Red blood cell (RBC); ROS: Reactive oxygen species; STAT: Signal transducers and activators of transcription; WBC: White blood cell}

\section{Acknowledgments}

Authors express deep gratitude to the Department of Biochemistry, Babcock University for providing support and research facility that enabled the completion of this study. We thank Mrs. Anyasor, Chiamaka for editorial assistance.

\section{Authors' contributions}

GNA and $A A O$ conceived and designed the experiment; GNA, AAO, and BO performed the experiment and acquired the data; GNA and BO analyzed and interpreted the data; GNA and AAO drafted the manuscript and all authors read and approved the manuscript.

\section{Funding}

This research work did not receive any specific funding

\section{Availability of data and materials}

All data pertaining to this study have been included in the manuscript

\section{Ethics approval}

The animal experiment was performed in accordance with the animal care and use guideline set by the National Institute of Health and Babcock University Health Research Ethics Committee approval was obtained. Justicia secunda leaves were obtained in fresh condition from a farm at Usaka-
Umuofor, Isiala Ngwa North, South-Eastern, Nigeria. The plant was identified and authenticated at Forestry Research Institute of Nigeria, Ibadan, Oyo State with voucher specimen number 112177.

\section{Consent for publication}

Not applicable

\section{Competing interests}

The authors declare no financial and non-financial competing interest with regards to this work.

Received: 31 July 2019 Accepted: 11 December 2019

Published online: 27 December 2019

\section{References}

1. Sofowora A, Ogunbodede E, Onayade A. The role and place of medicinal plants in the strategies for disease prevention. Afr J Tradit Complement Altern Med. 2013;10(5):210-29. https://doi.org/10.4314/ajtcam.v10i5.2.

2. Jamshidi-Kia F, Lorigooini Z, Amini-Khoei H. Medicinal plants: past history and future perspective. J Herbmed Pharmacol. 2017;7(1):1-7. https://doi.org/ 10.15171/jhp.2018.01.

3. Prakash B, Kujur A, Yadav A. Drug synthesis from natural products: historical overview and future perspective. In Synthesis of medicinal agents from plants. 2018. pp. 25-40. https://doi.org/10.1016/b978-0-08102071-5.00002-7.

4. Carrington S, Cohall DH, Gossell-Williams M, Lindo JF. The antimicrobial screening of a barbadian medicinal plant with indications for use in the treatment of diabetic wound infections. West Indian Med J. 2012;62(9):8614. https://doi.org/10.7727/wimj.2011.223.

5. Onoja SO, Ezeja MI, Omeh YN, Onwukwe BC. Antioxidant, antiinflammatory and antinociceptive activities of methanolic extract of Justicia secunda Vahl leaf. Alexandria J Med. 2017;53:207-13. https://doi org/10.1016/j.ajme.2016.06.001.

6. Herrera-Mata H, Rosas-Romero A, Crescente VO. Biological activity of "Sanguinaria" (Justicia secunda) extracts. Pharm Biol. 2002;40(3):206-12. https://doi.org/10.1076/phbi.40.3.206.5826.

7. Koné WM, Koffi AG, Bomisso EL, Tra Bi FH. Ethnomedical study and iron content of some medicinal herbs used in traditional medicine in cote d'Ivoire for the treatment of anaemia. Afr J Tradit Complement Altern Med. 2012;9(1):81-7. https://doi.org/10.4314/ajtcam.v9i1.12.

8. Mpiana PT, Ngbolua KTNN, Bokota MT, Kasonga TK, Atibu EK, Tshibangu DST, Mudogo V. In vitro effects of anthocyanin extracts from Justicia secunda Vahl on the solubility of haemoglobin $\mathrm{S}$ and membrane stability of sickle erythrocytes. Blood Transfus. 2010;8(4):248-54. https://doi.org/10.2450/ 2009.0120-09.

9. Pierre M, Danho PA, Calixte B, Djédjé SD, Goueh GBJ. Evaluation of the antihypertensive activity of total aqueous extract of Justicia secunda Vahl (Acanthaceae). Afr J Pharm Pharmacol. 2011;5(16):1838-45. https://doi.org/ 10.5897/ajpp11.131

10. Koffi EN, Le Guernevé C, Lozano PR, Meudec E, Adjé FA, Bekro YA, Lozano YF. Polyphenol extraction and characterization of Justicia secunda Vahl leaves for traditional medicinal uses. Ind Crop Prod. 2013;49:682-9. https:// doi.org/10.1016/j.indcrop.2013.06.001.

11. Shah BN, Seth AK, Maheshwari KM. A review on medicinal plants as a source of anti-inflammatory agents. Res J Med Plants. 2011;5(2):101-15. https://doi.org/10.3923/rjmp.2011.101.115.

12. Bosma-Den Boer MM, Van Wetten ML, Pruimboom L. Chronic inflammatory diseases are stimulated by current lifestyle: How diet, stress levels and medication prevent our body from recovering. Nutr Metab (Lond). 2012; 9(1):32. https://doi.org/10.1186/1743-7075-9-32.

13. Aziz M, Jacob A, Yang WL, Matsuda A, Wang P. Current trends in inflammatory and immunomodulatory mediators in sepsis. J Leukoc Biol. 2013;93(3):329-42 10.1189/jlb.0912437.

14. Du C, Bhatia M, Tang SCW, Zhang M, Steiner T. Mediators of inflammation: inflammation in cancer, chronic diseases, and wound healing. Mediat Inflamm. 2015; Article ID 570653. https://doi.org/10.1155/2015/570653.

15. Chen L, Deng H, Cui H, Fang J, Zuo Z, Deng J, Li Y, Wang X, Zhao L. Inflammatory responses and inflammation-associated diseases in organs. Oncotarget. 2017;9(6):7204-18. https://doi.org/10.18632/oncotarget.23208. 
16. Chistiakov DA, Melnichenko AA, Grechko AV, Myasoedova VA, Orekhov AN Potential of anti-inflammatory agents for treatment of atherosclerosis. Exp Mol Pathol. 2018;104(2):114-24. https://doi.org/10.1016/j.yexmp.2018.01.008.

17. Meyer M, Rastogi P, Beckett C, McHowat J. Phospholipase A2 inhibitors as potential anti-inflammatory agents. Curr Pharm Des. 2005;11(10):1301-12. https://doi.org/10.2174/1381612053507521.

18. McCarberg B, Gibofsky A. (2012). Need to develop new nonsteroidal antiinflammatory drug formulations. Clin Ther. 2012;34(9):1954-63. https://doi. org/10.1016/j.clinthera.2012.08.005.

19. Wongrakpanich S, Wongrakpanich A, Melhado K, Rangaswami J. A comprehensive review of non-steroidal anti-inflammatory drug use in the elderly. Aging Dis. 2018;9(1):143-50. https://doi.org/10.14336/ad.2017.0306.

20. Chandra S, Chatterjee P, Dey P, Bhattacharya S. Evaluation of in vitro antiinflammatory activity of coffee against the denaturation of protein. Asian Pac J Trop Biomed. 2012;2(1):178-80. https://doi.org/10.1016/S22211691(12)60154-3.

21. Shinde UA, Phadke AS, Nair AM, Mungantiwar AA, Dikshit VJ, Saraf M. Membrane stabilizing activity a possible mechanism of action for the antiinflammatory activity of Cedrus deodara wool oil. Fitoterapia. 1999;70:251-7.

22. Oyedapo OO, Akinpelu BA, Akinwunmi KF, Adeyinka MO, Sipeolu FO. Red blood cell membrane stabilizing potentials of extracts of Lantana camara and its fractions. Int J Plant Physiol Biochem. 2010;2(4):46-51.

23. National Institute of Health (NIH). Guide for the care and use of laboratory animals. 8th ed. Washington D.C.: The National Academies Press; 2011.

24. Winter CA, Risley EA, Nuss GW. Carrageenin-induced edema in hind paw of the rat as an assay for antiiflammatory drugs. Proc Soc Exp Biol Med. 1962:111:544-7.

25. John AAN. Shobana, G. anti-inflammatory activity of Talinum fruticosum L. on formalin induced paw edema in albino rats. J Appl Pharm Sci. 2012;2(1):123-7.

26. Cragg GM, Newman DJ. Natural products: a continuing source of novel drug leads. Biochim Biophys Acta, Gen Subj. 2013;1830(6):3670-95. https:// doi.org/10.1016/j.bbagen.2013.02.008.

27. Gunathilake K, Ranaweera K, Rupasinghe H. In vitro anti-inflammatory properties of selected green leafy vegetables. Biomed. 2018;6(4):107. https:// doi.org/10.3390/biomedicines6040107.

28. Ngoua-Meye-Misso R-L, De JNLC, Sima-Obiang C, Ondo JP, Ndong-Atome GR, Abessolo FO, Obame-Engonga L-C. Phytochemical studies, antiangiogenic, anti-inflammatory and antioxidant activities of Scyphocephalium ochocoa Warb. (Myristicaceae), medicinal plant from Gabon. Clin Phytosci. 2018;4(19):15 10.1186/s40816-018-0075-x.

29. Sangeetha G, Vidhya R. In vitro anti-inflammatory activity of different parts of Pedalium murex (L.). Int J Herb Med. 2016;4(3):31-6.

30. Ikwegbue PC, Masamba P, Oyinloye BE, Kappo AP. Roles of heat shock proteins in apoptosis, oxidative stress, human inflammatory diseases, and cancer. Pharmaceuticals. 2018;11(2):E2. https://doi.org/10.3390/ph11010002.

31. Labu ZK, Laboni FR, Tarafdar M, Howlader MSI, Rashid MH. Membrane stabilization as a mechanism of anti-inflammatory and thrombolytic activities of ethanolic extract of arial parts of Spondiasis pinanata (family: Anacardiaceae). Pharmacologyonline. 2015;2:44-51.

32. Ranasinghe $P$, Ranasinghe $P$, Abeysekera WP, Premakumara GA, Perera YS Gurugama P, Gunatilake SB. In vitro erythrocyte membrane stabilization properties of Carica papaya L. leaf extracts. Pharm Res. 2012;4(4):196-202. https://doi.org/10.4103/0974-8490.102261.

33. Kitadi JM, Lengbiye EM, Gbolo BZ, Inkoto CL, Muanyishay CL, Lufuluabo GL, Tshibangu DST, Tshilanda DD, Mbala BM, Ngbolua K, Mpiana PT. Justicia secunda Vahl species: phytochemistry, pharmacology and future directions: a mini-re-7view. Discov Phytomed. 2019;6(4):157-71. https://doi.org/10. 15562/phytomedicine.2019.93.

34. Ahmed SMU, Luo L, Namani A, Wang XJ, Tang X. NRF2 signaling pathway: pivotal roles in inflammation. Biochim Biophys Acta Mol Basis Dis. 2017; 1863(2):585-97. https://doi.org/10.1016/j.bbadis.2016.11.005.

35. Chen XL, Dodd G, Thomas S, Zhang X, Wasserman MA, Rovin BH, Kunsch C. Activation of Nrf2/ARE pathway protects endothelial cells from oxidant injury and inhibits inflammatory gene expression. Am J Physiol Heart Circ Physiol. 2006;290:1862-70.

36. Illesca P, Valenzuela R, Espinosa A, Echeverría F, Soto-Alarcon S, Ortiz M, Videla LA. Hydroxytyrosol supplementation ameliorates the metabolic disturbances in white adipose tissue from mice fed a high-fat diet through recovery of transcription factors Nrf2, SREBP 1c, PPAR- $y$ and NF-KB. Biomed
Pharmacother. 2019;109:2472-81. https://doi.org/10.1016/j.biopha.2018.11. 120 Epub 2018 Dec 1

37. Valenzuela R, Illesca P, Echeverría F, Espinosa A, Ángel Rincón-Cervera M, Ortiz M, Hernandez-Rodas MC, Valenzuela A, Videla LA. Molecular adaptations underlying the beneficial effects of hydroxytyrosol in the pathogenic alterations induced by a high-fat diet in mouse liver: PPAR-a and Nrf2 activation, and NF-kB down-regulation. Food Funct. 2017;8(4): 1526-37.

38. Kirkby NS, Chan MV, Zaiss AK, Garcia-Vaz E, Jiao J, Berglund LM, Verdu EF, Ahmetaj Shala B, Wallace JL, Herschman HR, Gomez MF, Mitchell JA. Systematic study of constitutive cyclooxygenase-2expression: role of NF-KB and NFAT transcriptional pathways. PNAS. 2016;113(2):434-9. https://doi.org/ 10.1073/pnas.1517642113.

39. Basua A, Dasa AS, Sharmaa M, Pathakb MP, Chattopadhyayb P, Biswasc K, Mukhopadhyaya R. STAT3 and NF-kB are common targets for kaempferolmediated attenuation of COX 2 expression in IL-6-induced macrophages and carrageenan-induced mouse paw edema. Biochem Biophys Rep. 2017; 12:54-61.

40. Bulus A, Abdul KH. Studies on the use of Zizyphus spina-christi against pain in rats and mice. Afr J Biotechnol. 2007;6:1317-24.

41. Hafeez A, Jain U, Sajwan P, Srivastava S, Thakur A. Evaluation of carrageenan induced anti-inflammatory activity of ethanolic extract of bark of Ficus virens Linn. In swiss albino mice. J Phytopharmacol. 2013;2(3):39-43.

42. Gupta R, Lohani M, Arora S. Anti-inflammatory activity of the leaf extracts/ fractions of Bryophyllum pinnatum saliv.syn. Int J Pharma Sci Rev Res. 2010:3:16-8.

43. Sandeep B, Kangralkar VA, Yuvaraj M, Megha T, Nilesh C. Anti-inflammatory, antiarthritic, analgesic and anticonvulsant activity of Cyperus essential oils. Int J Pharm Pharm Sci. 2010;2:112-5.

44. Hashem MM, Salama MM, Mohammed FF, Tohamy AF, El Deeb KS. Metabolic profile and hepatoprotective effect of Aeschynomene elaphroxylon (Guill. \& Perr.). PLoS One. 2019;14(1):e0210576. https://doi.org/10.1371/ journal.pone.0210576.

45. Chinnappan SM, George A, Thaggikuppe P, Choudhary YK, Choudhary VK, Ramani Y, Dewangan R. Nephroprotective effect of herbal extract Eurycoma longifolia on paracetamol-induced nephrotoxicity in rats. Evid-Based Complement Altern Med. 2019; https://doi.org/10.1155/2019/4916519.

46. Tungmunnithum D, Thongboonyou A, Pholboon A, Yangsabai A. Flavonoids and other phenolic compounds from medicinal plants for pharmaceutical and medical Aspects: An overview. Medicines. 2018;5(3):E93. https://doi.org/ 10.3390/medicines5030093.

47. Gawaz M, Vogel S. Platelets in tissue repair: control of apoptosis and interactions with regenerative cells. Blood. 2013;122(15):2550-4. https://doi. org/10.1182/blood-2013-05-468694.

48. Fleit HB. Chronic inflammation. In pathobiology of human disease: a dynamic encyclopedia of disease mechanisms 2014. https://doi.org/10.1016/ B978-0-12-386456-7.01808-6.

49. Chou CT. The anti-inflammatory effect of Tripterygium wilfordii hook F on adjuvant-induced paw edema in rats and inflammatory mediators release. Phytother Res. 1997;11:152-4.

50. Okoli CO, Akah PA, Onuoha NJ, Okoye TC, Nwoye AC, Nworu CS. Acanthus montanus: an experimental evaluation of the antimicrobial, antiinflammatory and immunological properties of a traditional remedy for furuncles. BMC Complement Altern Med. 2008;8:27-37.

51. Prempeh ABA, Mensa-Attipoe J. Crude aqueous extract of the root bark of Zanthoxylium xanthoxyloides inhibits white blood cells migration in acute inflammation. Ghana Med J. 2008:42:117-9.

\section{Publisher's Note}

Springer Nature remains neutral with regard to jurisdictional claims in published maps and institutional affiliations. 